\title{
Early Navigation in the North Sea - The Use of the Lead and Line and other Navigation Methods
}

\author{
John Kemp and Brian D’Olier
}

(E-mail: prof.kemp@talk21.com)

\begin{abstract}
Every sailor, at the back of his or her mind, is aware that the nearest land is likely to be directly beneath the ship's keel and he or she is interested to know just how near. For over two thousand years, mariners measured depth of water by using a sounding rod in shallow areas and the lead and line in deeper water. This paper considers how, during the "Dark Ages", sailors in the North Sea might have navigated, including the use of sounding rods and lead lines for way-finding during a time when no other navigational instruments were available. Because of the lack of contemporary records the authors firstly consider the use of depth finding in earlier and later times to shed light on how the early North Sea sailors might have operated. The latter part of this paper takes account of the earlier discussion, together with some records of North Sea voyaging, to suggest how "Dark Age" sailors might have used sounding rods, the lead and line, and other techniques to navigate around and across the North Sea.
\end{abstract}

\section{KEYWORDS \\ 1. Lead Line. $\quad$ 2. Sounding Rod. $\quad 3$. North Sea. $\quad$ 4. Dark Ages.}

Submitted: 21 October 2015. Accepted: 17 November 2015. First published online: 23 December 2015.

1. INTRODUCTION. This paper attempts to address the question as to the navigation techniques used by North Sea sailors during the "Dark Ages". This is an imprecise period and modern authors tend to avoid the term, but it is a useful label and, for the purpose of this paper, it is taken to cover the period from late Roman times to early medieval times, say from 400 to 1200 AD. The phrase "Dark Ages" was coined for good reason. Few records are available from that time to provide evidence of how sailors found their way in the misty, stormy and strongly tidal waters off the coasts of northwest Europe. It was, however, a busy time for North Sea shipping with Frisian traders dominating from Roman times until the coming of the Vikings during the ninth century. There was also the migration of the Saxons, Angles, Jutes and other tribes from the Northern European mainland to the Eastern and Southern shores of England. In the eleventh century, there were nearly simultaneous 


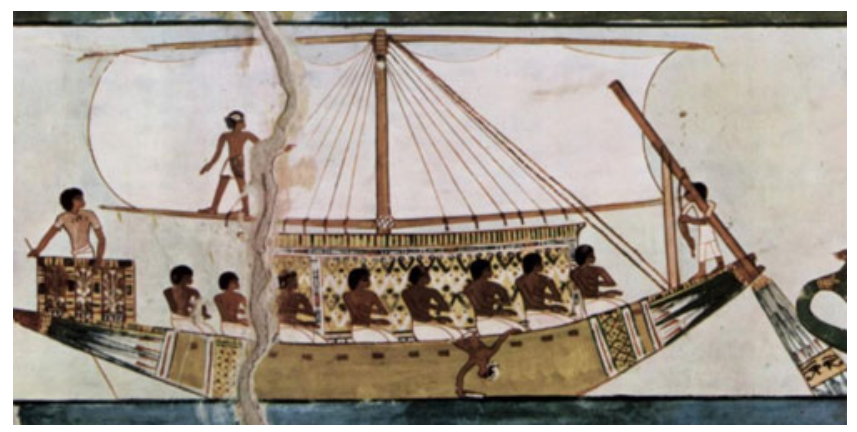

Figure 1. Use of a sounding rod on an Egyptian ship, c. 1250 BC.

attacks by a Norwegian fleet across the North Sea and a Norman fleet across the English Channel.

May (1973) tells us that it was "shortly before 1200 AD that the magnetic compass was first used by some ships in European waters." This suggests that its use developed in the North Sea during the thirteenth century. Prior to that, with the possible exception of a simple Sun-compass possessed by the Vikings (Thirslund, 2007), the authors know of no navigational instrument, generally available to sailors, other than the lead line and the sounding rod. These devices were almost certainly used for measuring depth of water by "Dark Ages" seamen in the North Sea but clues as to the method of use, or how extensively they were used, are sparse. To address this problem, the authors first look at the recorded use of the sounding rod and the lead line in earlier times, and again during later times, as a way of inferring how they might have been used during the study period.

2. EGYPTIANS AND ROMANS. In ancient times, charts were virtually non-existent but the depth of water could be measured by a sounding lead and line or, in shallow water, by sounding rods (see Figure 1).

Egyptian ships have been depicted as using sounding rods to ascertain the depth of water from the third millennium BC. They were clearly an important aid to safe navigation of the Nile and its delta where sandbanks and channels could change significantly during each inundation. At later times, as ships traded into the Mediterranean and the Red Seas, the lead and line appeared, the earliest recorded mention being that by Herodotus (440 BC) who wrote that, when approaching the Nile estuary from seaward, a depth of eleven fathoms, with a bottom sample of mud, indicated that the ship would be a day's sail from Alexandria. It seems likely that the sailors also realised that the sediments became steadily coarser as the land was approached, and they may well have been able to position themselves across the delta by reference to the submarine distribution channels that gently snake across the delta, taking the main water and sediment movement from the river to the outer parts.

The quotation from Herodotus is of particular interest because it confirms that sailors at that time were interested in the nature of the seabed as well as the actual depth of water. This is supported by the discovery of the earliest known sounding 
lead from a ship that sank at Gela, Sicily, about fifty years before Herodotus wrote his history. This find is described by Oleson (2008) as "a flattened hemisphere with slightly flattened sides and shallow tallow cup, made of lead." The purpose of the tallow was to pick up a sample of the sea bed.

The lead line was widely used in the Mediterranean Sea during Graeco-Roman times, as evidenced by the database of over 150 recovered sounding weights identified by Oleson (2008) as being from this period. A graphic account of the use of sounding leads in Roman ships is contained in the Biblical account of St Paul's shipwreck that took place in about $60 \mathrm{AD}$. When the sailors sensed that land was near, they dropped a line and measured 20 fathoms. A little further on, they dropped the line again and found 15 fathoms. They then threw out anchors from the stern to prevent stranding on the lee shore. In the morning, they cut the anchor ropes and the ship was blown towards the shore where it grounded on a sandbank. (See The Bible, King James Version, Acts, chapter 27, verses 27-32).

Oleson (2008) tells us that "a typical Roman sounding weight was a roughly bell shaped, lead casting, of about five kilograms with a sturdy attachment lug at its apex for a rope and a depression in its spreading base for tallow" He also provides evidence, in a quotation from Festus, that the Roman nautical practice was that "those who travel in boats make trial with a pole and find the depth of water."

3. NORTH SEA NAVIGATORS IN ROMAN TIMES. From archaeological records, there is no doubt that the lead and line was a useful navigation tool for Mediterranean sailors. It might well have been developed independently by sailors in the North Sea but, in any case, it would surely have been introduced in that area as the Roman Empire expanded towards the North-West and, by the time of St Paul's shipwreck, it included Britain. Strabo (20 AD) describes ships used by the Veneti, a tribe which lived in what is now northwest France. These ships had sails and were built of oak, and they had anchor cables of iron chain. The Veneti regularly sailed to Britain and, although there is no record as to whether they used lead and line, it seems unlikely that they did not, especially after their contact with the Romans.

If the lead and line was useful to the Mediterranean sailors where much of the coastline is steep-to, with deep water close to the land, and visibility is generally good, then how much more useful it must have been to early sailors in the southern North Sea. There, the coastlines are generally low, with few distinguishing features. There are many offshore shoals and visibility is often poor. Finally, there are the tides which not only change the depth of water, but also generate tidal streams whose rate is similar to the speed at which ancient boats could be sailed or rowed.

In this context, it should be noted that anchors had additional uses in the North Sea as compared with the Mediterranean. For example, boats could ride out the six hours of an adverse tide rather than attempting the fruitless task of rowing or sailing against it. Anchors were also needed to safely kedge off a beach or sandbank on a rising tide after a boat had taken the ground accidentally, or deliberately to load or discharge passengers or cargo.

There is no doubt that there was considerable traffic in the southern North Sea during Roman times. The close contact between Britain and mainland Europe, evident at the time of the initial invasion of Britain, was subsequently maintained. Hassall (1978) tells us that, in addition to significant trade, legionary detachments 
were sent as reinforcements from the Rhineland to Britain or vice versa as need arose. Sometimes, he notes, complete legions were moved, as when Legion VI came to Britain from lower Germany early in Hadrian's reign, probably sailing directly from the Low Countries to Newcastle. There, they dedicated altars to both Neptune and Oceanus, which seems like a "belt and braces" approach to thanking whichever of the two gods might have been responsible for their safe crossing of the North Sea.

Hassall (1978) also makes the point that nearly all the ethnic groups to the west of the Rhine delta were represented among the Roman Army in Britain, and there were even some from groups (including the Frisians) from areas to the east of the delta. There must surely also have been sailors from these groups helping to man the ships that carried the troops. It is extremely unlikely that the Romans could have safely navigated the treacherous, tide dominated, waters of the southern North Sea without advice from mariners with local knowledge.

Less well documented is the non-military traffic, but geographical evidence suggests that it was extensive. As Cleere (1978) has pointed out, London was the most important commercial centre for Roman Britain. Its east-facing estuary strongly suggests that ships took a direct route from London to and from the Low Countries and the Rhineland, with which much of the trade was exchanged. Direct routes across the North Sea are also suggested by the chain of forts designed by the Romans to protect the "Saxon Shore." It is significant that the earliest of these were built at Brancaster (Norfolk) to protect the approaches to the Wash, and at Reculver (Kent) to guard the Thames estuary.

Even before the Romans left northwest Europe, there were movements of the northern European tribes towards the west, and some as far as Britain. As the Roman grip weakened, the North Sea became the route by which Saxons (from what is now northern Germany), Angles (from what is now southern Denmark) and Jutes (from what is now northern Denmark), and some Frisians (from what is now the northern Netherlands) migrated towards the west, with many reaching as far as Britain (Pye, 2014). However, Pye tells us that it was those Frisians who stayed at home who became the most important traders in the North Sea as their base expanded from the Rhine delta as far east as the Weser. By 600 AD they had achieved a near monopoly of trading in the area and they maintained this until the coming of the Vikings in around $800 \mathrm{AD}$.

It is the post-Roman period, from 400 to 1200 AD that is the real focus of this paper, but there is little direct evidence of how the mariners navigated in northwest Europe during that time. Some evidence from preceding years in the Mediterranean Sea has been discussed and the Roman link to North Sea shipping has been noted. We now turn to consider the use of the lead and line in later times.

\section{LATER USE OF THE LEAD AND LINE.}

4.1. Water depth and the nature of the seabed. The introduction of the magnetic compass in the $13^{\text {th }}$ Century (May, 1973) made life easier for North Sea sailors, but it provided information that complemented the lead and line without replacing it.

Following the Viking period, the ships of the Hanseatic League became the principal actors in the North Sea and Baltic Sea trades (Pye, 2014). The League remained in business from the $14^{\text {th }}$ Century until the $17^{\text {th }}$ Century. It was formed by the coming together of the commercial maritime interests of a diverse group of cities. It developed 
rules and regulations for the greater good of its members and, in some cases, despite many internal disputes, it wielded greater power than sovereign states of the time. Clearly, in the interests of profitable trade, it was necessary for ships to navigate safely on their voyages. The author has found no Hanseatic records of how the preeminent navigation aid, the lead and line, was used in practice, but we do have an independent $15^{\text {th }}$ Century reference relating to the English Channel.

Taylor (1957) tells us that the first English "rutter", dating from c. 1470, lists what was to be found on the seabed in the approaches to the English Channel as follows:

In Belle isle there is in 60 fathoms or 70, small sand. Off Penmarche there is in 50 fathoms black ooze and in 60 fathoms there is sandy ooze and black fishy stones. Off Ushant in 50 or 60 fathoms there is red sand and black stones and white shells among. Off Lizard there are great stones as it were beans and it is ragged stone. Off Portland there is fair white sand and 24 fathoms with red shells therein, and in 14 or 16 fathoms there is rocky ground and in some places there is fair clay.

This confirms the importance given by mariners to the nature of the sea bed and must reflect observations made over many years during which seamen accumulated, and handed down verbally from generation to generation, a vast database of depth/ground pairings.

Also worthy of note is the considerable depth of water from which the samples were retrieved. In shallow water, a sounding can be taken while a ship is under way by casting the line some way ahead so that it becomes vertical when the lead hits the seabed. However, a ship would have had to be stopped to obtain an accurate sounding in water with a depth of more than about 20 fathoms. We should also be aware of the heavy labour involved in taking a series of deep sea casts. Repeatedly retrieving a long length of wet rope and a heavy deep-sea lead would have required considerable physical effort. The author can remember something of that when, as a cadet in 1948, and with the help of a hand winch, he had to repeatedly retrieve long lengths of the much lighter piano wire when attempting to locate the 100 fathom line as his ship approached the Irish coast from the North Atlantic.

From the $17^{\text {th }}$ Century onwards, seamen became more literate and navigation became more scientific. In his Seamans' Dictionary, Mainwaring (1644) included an entry for the deep-sea lead:

Deep-Sea-Lead is the lead which is hung at the deep-sea-line to sink it down, the weight whereof is commonly 14 pounds. This has some white hard tallow laid upon the lower end of it which brings up the ground, and so by the differences of the ground we know where and upon what coast we are [it being in such places as the sounding and ground is formerly known]. But in oozy ground we use a white woollen cloth upon the lead with a little tallow, without which cloth the ooze would not stick unto the tallow. Deep-Sea-Line is a small line with which we sound in deep waters to find ground; and so according to the depth and ground in many known places, as in the coming into our Channel and many other places, when we can see no land yet we know where we are.

That is a clear and forthright statement, confirming the use of depth/ground pairs for ascertaining a ship's position.

Specification of water depths and seabed characteristics were present in many later sailing directions and other records, which also included advice relating the soundings to distances offshore and to the courses that should be followed. May (c. 1970) discusses a number of such records in detail, up to the nineteenth century when Norie 
(1822) listed some questions and answers for the "examination of a young sea officer" including:

Q. In thick weather, how would you know when you are to the northward of Scilly?

A. By having 45 to 50 fathoms oozy bottom.

Q. What soundings would you get in the fairway of the Channel?

A. White sand, small yellow stones with black specks and broken shells.

Q. How do you know when you are on the French coast in thick weather?

A. By having deep water with large stones and red sand.

It is noteworthy that, in this exchange, the word "soundings" is taken to include the nature of the seabed rather than the depth of water alone, and the second answer omits any mention of the depth of water at all.

Despite such references, it has to be said that the lead and line continued to receive less attention in the literature than was its due. Sounding and finding one's way by measuring the depth of water and sampling the nature of the seabed was something that sailors did as a matter of routine. As a navigational technique, it had neither the mathematical neatness of dead-reckoning nor the glamour of astro-navigation and it was not thought to be worth writing about. Mark Twain (1883), belatedly, attempted to put this right in his book "Life on the Mississippi". More to the point, for the purposes of this paper, was an illuminating article in the UK Journal of Navigation, in which Cooper (2010) described how, in 1937, as a young boy, he accompanied his fishing-skipper father as he took his trawler to a North Sea fishing ground, fished, and returned to port. During the three days that he was away, he consulted no charts and navigated primarily by lead and line although he would, no doubt, have observed, visually, the lightships and buoys that were to be found near his route. Courses were set by a magnetic compass, reading points and quarter-points.

Information, provided privately by Lieutenant Commander Cooper, suggests that the fishing ground which formed the trawler's destination might have been "The Hills", situated to the southwest of the Dogger Bank. This area consists of ridges and intervening valleys, moderately fan-shaped (as described by Cooper), with water depths varying from shallows of 25 metres to deeps of 55-60 metres. They are aligned between $270-315^{\circ}$ and of course their reciprocals. They were originally deposited as sandbanks, formed as sea level rose and tidal activity began, following melting of the ice sheets of the last glaciation. The intervening valleys contain muddy sands lying over glacial, Bolder Bank Formation materials. These consist of weathered grey-brown clays, silts, sandy silts and fine sand, and some pebbles. Flat fish heaven!

The southernmost channel of The Hills, a westerly extension of the Outer Silver Pit, is called Skate Hole and is the first place where water depth exceeded 30 fathoms on the trawler's journey north from Lowestoft. That is except for the Coal Pit at approximately $53^{\circ} 30^{\prime} \mathrm{N} / 001^{\circ} 45^{\prime} \mathrm{E}$ and the much longer Sole Pit at approximately $53^{\circ} 35^{\prime} \mathrm{N} / 001^{\circ}$ $35^{\prime}$ E. These north/south aligned deeps would be useful lateral guides when sailing on a course on, or close to, due north or south, to and from Lowestoft. Sailing north and having passed Haisborough Bank, the last sandbank that was clearly marked (by the Haisboro light vessel), he would set a course at approximately $350^{\circ}$ that would take him to Skate Hole. As he went he would know if he had strayed to either east or west if, prematurely, water depths increased to more than 30 fathoms and thus he was over the glacially scoured deeps (pits). Incidentally, the seabed 


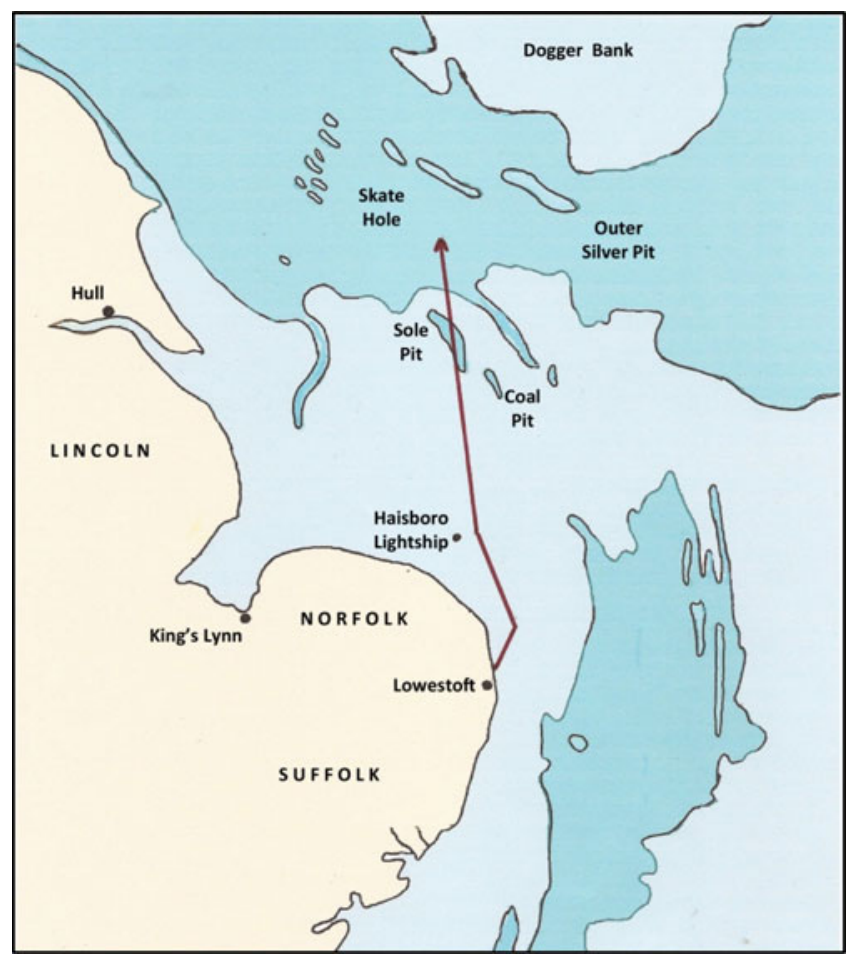

Figure 2. Possible outbound trawler route (in red) to the fishing ground in "The Hills" area of the North Sea. To keep the chart uncluttered, only the 30 metre depth contour is shown.

north of the Norfolk banks consists largely of a coarse, gravelly sand, often containing a high shell content rather than the fine/medium sand to the south.

On the way to the fishing ground, Cooper's trawler was stopped and the lead was cast at hourly intervals. As well as measuring the depth of water, a bottom sample was examined visually, smelt and tasted on each occasion. (Note: there is a scientific basis for the smell and taste because organic material in silt, silty clays and clays gives off the odourless methane gas, laced with pungent sulphurous fractions). The outward trip terminated in a kind of search pattern, when there were numerous casts of the lead "armed" with tallow, almost certainly to locate the muddy sands lying within troughs between the ridges. During the fishing operations, the lead was cast at ten-minute intervals while the ship was under way and the depth noted but no bottom sample was taken. This would have been to ensure that they were following a trough in the seabed, where the best flat fish were to be found. When the fishing was completed, the trawler was steamed in a number of circles at slow speed while further soundings were taken, perhaps to locate the increasingly coarser, less muddy sands on the south side of "The Hills" from which a course could be set for home. On the return voyage, with the boat under way, the lead was again cast every hour, and the course was adjusted as necessary. Cooper says that it took them straight to the Holm buoy, off Lowestoft.

The chart in Figure 2 shows the kind of track that might have been followed by the trawler from Lowestoft to the fishing ground in "The Hills" area south-west of the Dogger Bank. 


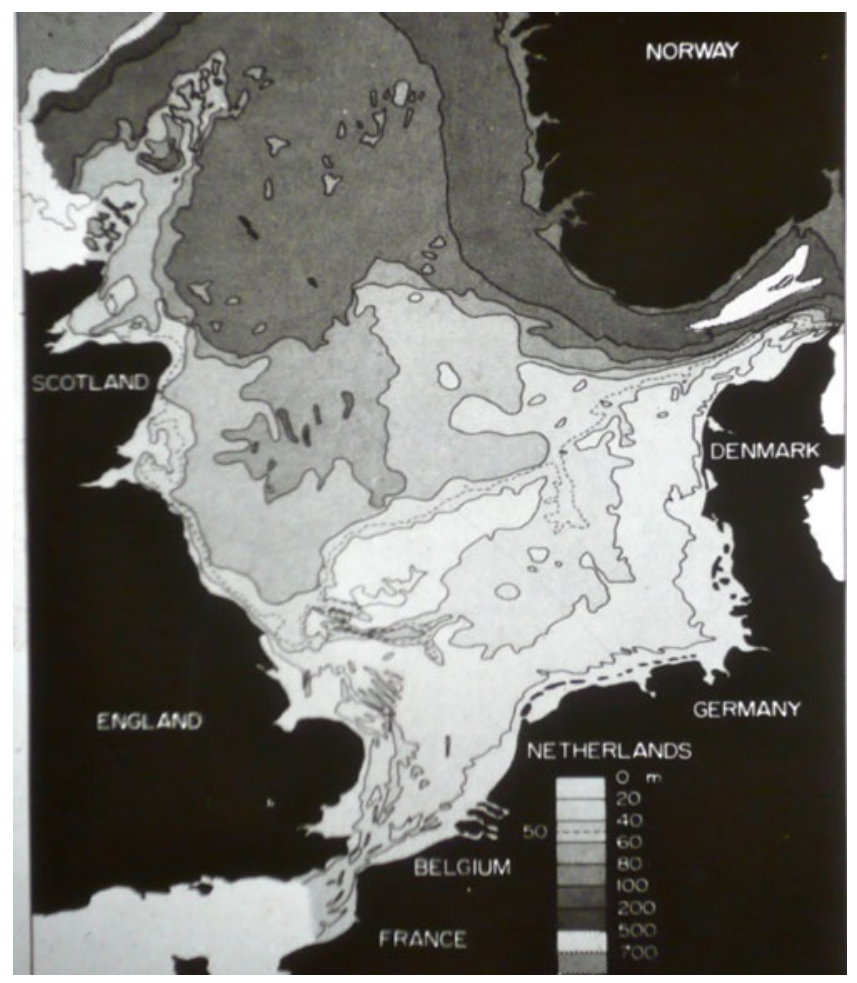

Figure 3. Bathymetric chart of the North Sea. (source Dr D’Olier).

The chart in Figure 3 is indicative of the distribution of water depths in the southern North Sea, though depths on charts are mostly displayed at ten metre intervals. Cooper's father and earlier sailors would surely have been able to measure depth to the nearest metre (approximately half a fathom) so they would have been able to make use of seabed contours to a much higher resolution than is shown on this chart. Increased resolution implies more precise positional information.

A knowledge of the distribution of different sea-bed materials for comparison with samples, obtained from an "armed" sounding lead, clearly provides important evidence of a ship's position. The chart, reproduced at Figure 4, shows the distribution of a number of sediments across the bed of the North Sea. Cooper's fishermen had a much more detailed knowledge, including types of shell, the colour of deposits, and variations in smell and taste. As we have noted, there is a record of seamen possessing such detailed knowledge from the fifteenth century (except, perhaps for taste and smell).

The following information offers a more detailed breakdown of seabed materials off the East coast of England than is shown by Figure 4. The type of shell is often distinctive for a locality not only because shell-fish live and die there at present but also because in the past during earlier phases of sea level rise, particularly over the period 12,000 to about 9000 BP (Before Present), different marine shelly molluscs inhabited particular areas of the newly submerged, steadily deepening seabed. For instance, mussels and oysters in very shallow water, cockles in areas of shallow muddy 


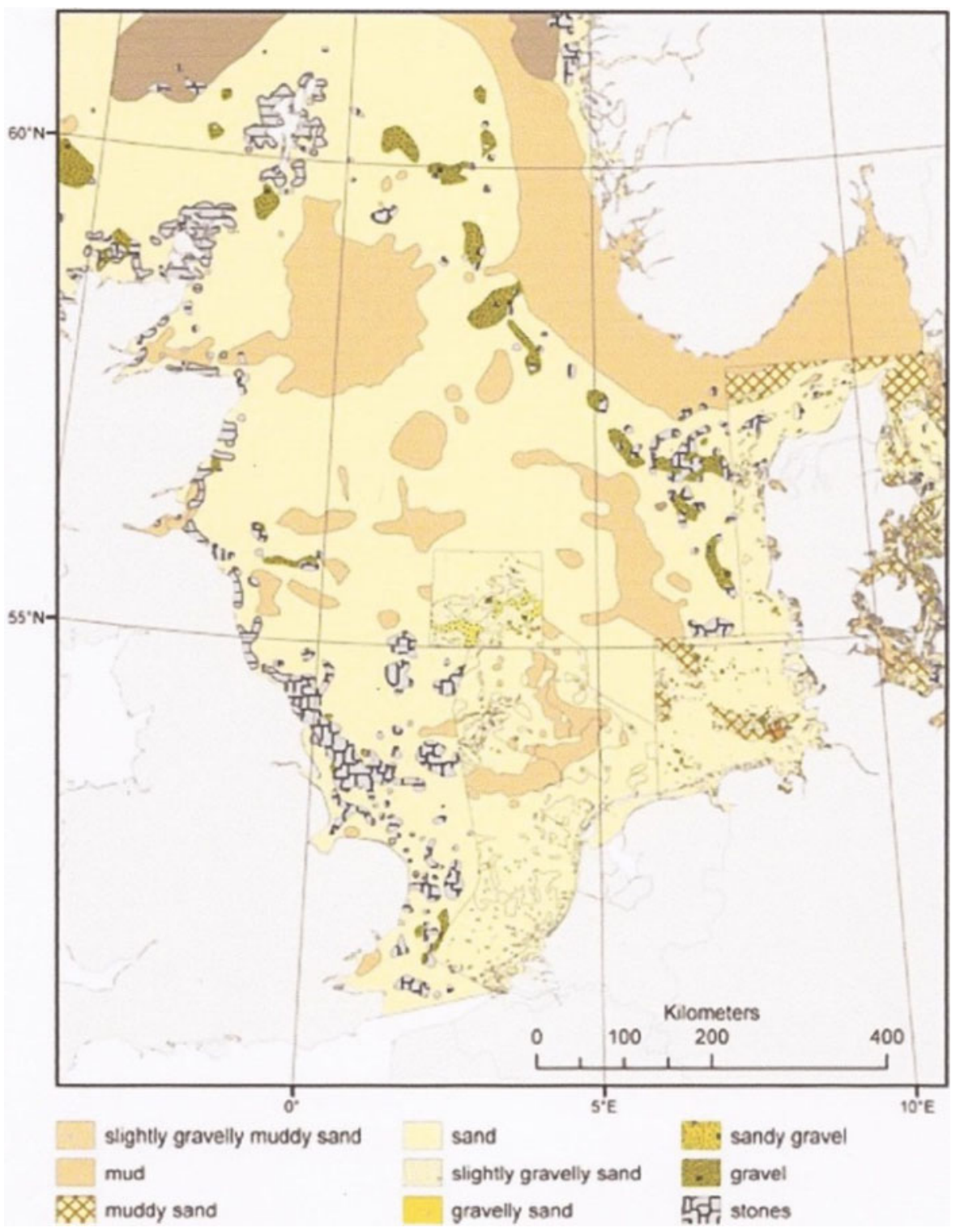

Figure 4. Distribution of main seabed sediments in the North Sea (From European Commission Atlas of the North Sea).

sands, scallops in deeper areas. Also, within the outer reaches of the Thames Estuary and in the Southern Bight there are identifiable patches of ancient oyster beds. These distinctive ancient shelly patches would have been a useful navigational guide for sailors down the ages, as would the type of stone, as was recorded within the first English 'rutter'. In the case of Cooper's trawler voyage, the gravel changes from chalk flint in the south to a mixed variety of igneous and sedimentary rock types in the more northerly section of his course, brought there originally by the ice sheet. 
Lobes of ice came into the North Sea from Scotland and others from Norway carrying within each a differing assemblage of rock types consisting of sizes ranging from boulders to pea gravel. Further north these changes and variations of glacially deposited rock type would again have been a useful guide to early navigators.

In addition, an indicator of approaching land would have been land-derived flotsam particularly as river mouths were approached or the coastal regions of Yorkshire and Lincolnshire. These coastlines, consisting of easily erodible glacial clay - Bolders Bank Formation - have been eroding rapidly, as they still are, since the sea level began to rise, depositing their surface vegetation and trees into the sea. Clearly, the seabed of the North Sea was, and is, a rich source of positional information for sailors. It would be surprising if "Dark Ages" sailors did not make some use of it since little else was available to them to aid their navigation.

4.2. Observation of the water surface. At this point, we should remember that depth of water and the presence of 'reef like features' can sometimes be estimated by observing the sea surface, without the need for lead and line or a sounding pole. Again, it seems that it was necessary to wait for Mark Twain (1883) to write a detailed explanation as to how this might be done. In one passage, Twain's tutor explains, "Do you see that long slanting line on the face of the water? Now that's a reef. . . . There is plenty of water close up to it, but mighty little on top of it . . . Do you see where the line fringes out at the upper end and begins to fade away? Well that is a low place... You can climb over there." Twain eventually learned to tell the difference between a line on the water caused by wind and a line caused by a submerged reef although neither he nor his tutor could explain in words what the difference was. Twain's experience was in the context of the Mississippi River rather than the rougher waters of the North Sea but, although the accuracy at sea would certainly have been less, the principles remain valid.

In the 1970s, co-author, Dr Brian D'Olier, had built up a detailed knowledge of the seabed topography in and around the Thames Estuary. In this familiar area, he was able, in reasonably calm conditions, to discern the form of both sandbanks and associated sand-waves by observing the patterns of water flow that could be seen over these features.

As an example, Figure 5 shows the principal seabed features within the Southern Bight created by the water flowing over them. If wave activity is relatively slight (wind speed $<$ force 3 ) during strong tidal flows this water movement becomes measurable by radar as a result of the water level being raised as it flows over a feature. These distinctive features are emphasised, as water flowing close to these features is refracted towards their crest lines where its velocity increases, thus adding to the variation in surface elevation relative to the parallel flowing, deeper water nearby. These variations are also observable locally at deck level where the sea surface looks slightly elevated as well as being roughened as it approaches the feature, and smoothed as the water increases in velocity in passing over and immediately beyond the feature. When these conditions prevail there is indeed ' $a$ line in the water' along a sandbank and a series of lines where there is a group of sub-parallel sand-waves. This latter feature can be seen most clearly in Figure 5 at the eastern end of the Sandettie.

Some clues are more obvious. Especially in bright weather, shallow water appears to be a lighter colour due to reflection of light from the seabed. Friction from a shallow seabed causes waves to steepen and to break more frequently than deep water. Tidal streams run more quickly in deep channels than over adjacent banks thus causing a velocity shear and the development of tidal "races." Isolated shoals or rocks lurking 


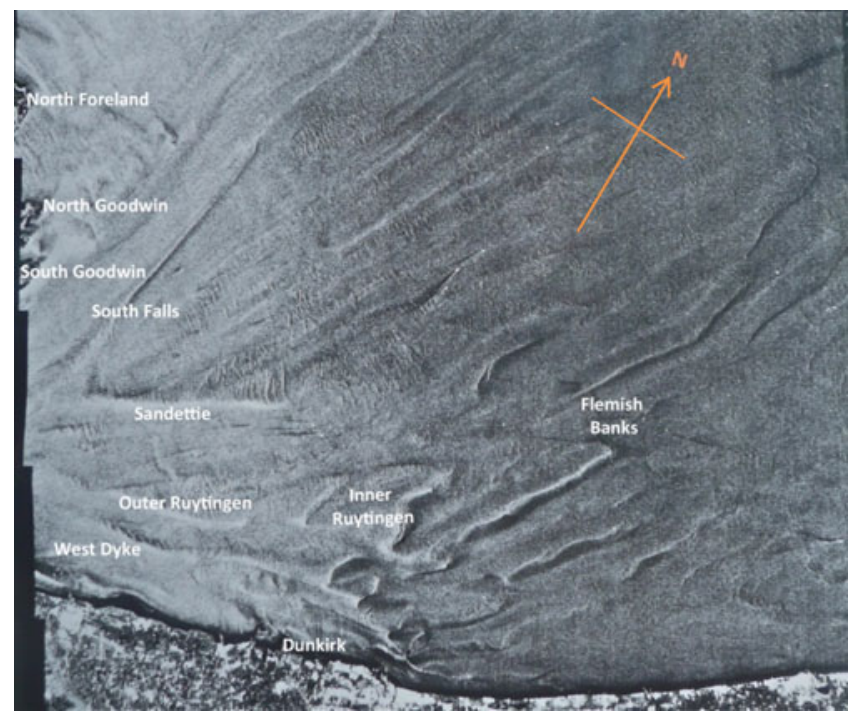

Figure 5. Synthetic aperture radar photograph of the Southern Bight area of the North Sea. Photograph by NASA, 1978. Identification of sandbanks by the authors.

just below the surface cause their own wave patterns that are superimposed on the ambient wave pattern in a sea area, and there is likely to be turbulence in the water on the downstream side. Nowadays, safe channels, shoal water and underwater hazards are marked on charts and sailors do not have to "read" the waters in the same way as Mark Twain, trawler skippers and, without doubt, the old North Sea navigators, learned to do as a matter of necessity.

A rare early record of "reading the water" was given by Sir Richard Hawkins (1593) as his ship approached the coast of Africa. He relates that, “... calling the captain and master of my ship, I told them that to my seeming, the water had become very whitish, and that it made show of sholde water." They explained to him that none of the lines in the ship could "fetch ground". Hawkins goes on to say that they all prayed to God but that, even as they did so, he remained uneasy and thought the water was becoming whiter and whiter. He therefore had another sounding taken and this time they found fourteen fathoms, which, he says, put them all into a "maze".

If the use of soundings, supplemented by observation of the sea surface, could have been used by 1930s fishermen as a primary aid to navigation, then it could, presumably, have been used, equally well, by early North Sea traders. They would, however, have had to rely on other means than the magnetic compass for direction. In clear weather, they would, no doubt have been able to use the Sun or the stars. In overcast conditions, perhaps wind and swell would have provided the necessary clues.

5. ESTIMATING DIRECTION BEFORE THE COMPASS. It is noteworthy that a number of commentators have suggested that the Sun could only have been used for establishing direction at noon each day, when it was at its maximum altitude and at which time, for North Sea sailors, its bearing would have been due south. Aside 
from the difficulty of knowing when the Sun had reached its maximum altitude, there is no reason why the Sun should not have been used for setting an approximate course at any time of the day. The sailors would surely have known how the Sun moved across the sky and have been able to make appropriate allowance for its change of direction according to the time of the day. This is something that insects such as ants and bees learn do with their relatively simple brains (Towne, 2008). It can have presented little problem to "Dark Age" sailors. Two thousand years is the blink of an eye in evolutionary time. Their world might have been simpler than ours, but their brainpower was no less. Lewis (1970) made voyages in the Pacific without the use of instruments to investigate the methods used by Polynesian and Micronesian navigators. Navigating by day, he reported that, "It became habitual to maintain course by the Sun, adjusting almost automatically to its changing bearing as it curves up on its arc. The process seems one of observation, judgement and experience rather than conscious measurement." Just so.

In a similar way, some commentators emphasise the pre-eminence of the Pole Star for maintaining a course at night, and perhaps with good reason. However, the sailors could also have followed setting stars when heading westerly and rising stars when heading easterly. In the latitude of the North Sea, brilliant stars like Rigel, Betelgeuse, Procyon, Spica and Altair all rise and set within little more than a point of due east or due west, respectively.

Finney (1993) tells us that Polynesian navigators "oriented themselves and set their course by night on the rising and setting points of key stars and constellations, and by day on the Sun when low in the sky, its changing position having been calibrated against the fading star field of the dawn sky." If the Polynesians and the Micronesians in the Pacific could use the Sun and stars in this way, then why not the Europeans in the North Sea? The heyday of Polynesian navigation is thought to have been somewhat later than the European "Dark Ages", although their voyaging had taken them as far as New Zealand by the thirteenth century (Lowe, 2008). Nevertheless, they had no magnetic compass so they had the same need as the North Sea mariners to set and maintain a course and, when south of the equator, there was the added challenge that they had no equivalent of the Pole star to guide them. Importantly, they were still using their traditional methods until well into the twentieth century so that Micronesian practitioners could sail with the likes of Gladwin (1970) and Lewis (1970) and demonstrate, first hand, how they set their courses by the Sun and the stars.

Clearly, it is possible to find one's way across the North Sea by using a sense of direction and information obtained by lead and line because, within living memory, it was known to have been done by the likes of Cooper's father. In the "Dark Ages", there was no magnetic compass but Sun and stars would have provided sufficient directional information to allow landfalls to be made in the vicinity of intended destinations. That would have left the old sailors with a need for local and more detailed navigation techniques to find their precise destination.

6. LOCAL NAVIGATION. An excellent description as to how soundings can be used to navigate through estuarine waters was given by Erskine Childers (1903) in his book, The Riddle of the Sands. Childers wrote from first-hand experience of cruising amongst the Frisian Islands in 1897 and 1898 in his yacht, Vixen, and again in 1903 in the Sunbeam. 


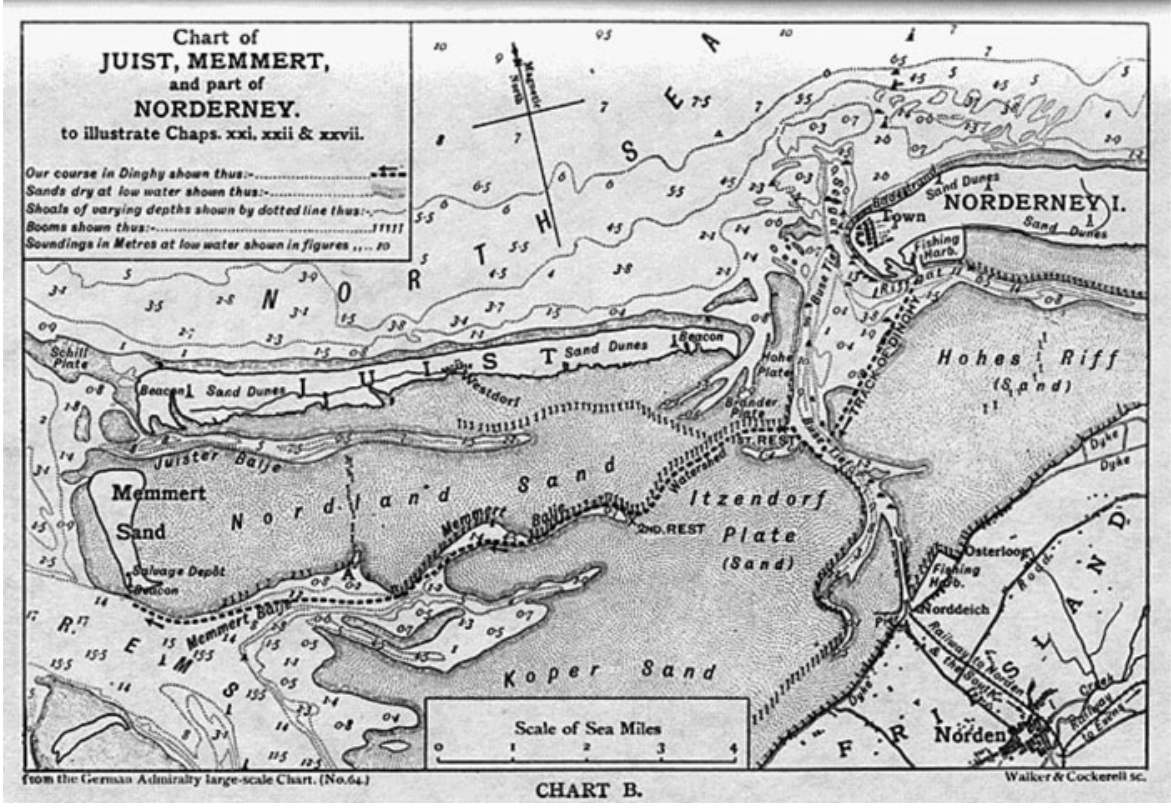

Figure 6. Chart from "The Riddle of the Sands." The ten mile journey marked by a pecked line, would have been made when the "Sands" were covered with water.

Armed with a chart of an area of the Frisian Islands off the coast of Germany (see Figure 6) Childers' character, Davies, was able to find his way on a foggy night by identifying and following the edges of channels. His sounding rod was a boathook with its shaft marked in feet. Where it was necessary to cross a channel, he did so at right angles, noting the "boiling" of the water which indicated that they were in a strong tideway. As Davies says in the book, "The chart may look simple ..... but, at half flood, all those banks are covered; the islands and coasts are scarcely visible; they are so low and everything looks the same."

Although not mentioned by Childers, navigation by sounding rod or lead line along a channel edge might be difficult in some places due to the ridge and furrow effect of sand-waves lying approximately at right angles to the axis of the bank.

Also, when sailing close to a sandbank the proximity of it might be judged, visually, by the strength and direction of the water flow as it becomes increasingly refracted towards the crest of the bank. The flow direction becomes increasingly closer to $45^{\circ}$ and the velocity increases as the crest is approached. This could be a hazard for sailing ships in light winds and at night or in mist.

Following a depth contour as described by Childers can still be a useful technique. The author's friend, Jac Spaans, was caught in fog when sailing along the north coast of the Netherlands from Den Helder to Ijmuiden. His boat had a depth finder and he used this to follow the ten metre depth contour. This is the kind of technique that could equally well have been used by early seamen although their lead lines would have required more physical effort than Jac's echo sounder. The ten metre contour (five fathoms to the old sailors) would have been enough to keep their boats clear of the dangerous breaking surf nearer the shore. 
The Dark Age sailors would have possessed no charts, but observation of their home estuaries at low water would have impressed on their minds the pattern of banks and channels through which they would need to navigate when they were covered by water.

Taking a boat into an unknown estuary would have required more care. It would certainly have been attempted on a rising tide so that a grounding would not be disastrous and to take advantage of the flood stream. The appearance of the water surface would provide clues as to where the deepest water and the fastest currents were to be found and would supplement soundings by rod or (less likely in relatively shallow water) by lead and line. In addition, the sailors would have possessed a general understanding of the behaviour of tidal streams in relation to the depth of water so that, for example, the fastest streams on the outside of bends scour greater water depths and, conversely, shoals tend to build up on the inside of bends.

Having discussed how the lead and line and the sounding rod were used before and after the "Dark Ages", we will move on to consider how, with these instruments as their only navigation aid, sailors during that period might have found their way around the North Sea.

7. DARK AGES NAVIGATION IN THE NORTH SEA. The lead and line might have been the only navigation aid available to early seamen in the North Sea, but they also had other means of finding their way through the direct use of their senses, just as animals use their senses to complete astonishing journeys when migrating, homing and hunting.

It has been postulated that animals (including unaided humans) need both a conceptual map, to relate the position of their destination to their present position, and a compass to enable them to fly, run or swim in an appropriate direction (Phillips et al., 2005). It has also been established that many animals are able to navigate by a number of different methods. For example, a pigeon, released at a distance from its loft, may find its way home by landmarks in familiar territory, by reference to the Sun in unfamiliar territory, and by the Earth's magnetic field or olfactory cues in overcast conditions (Walcott, 1996). It would therefore be strange if early North Sea navigators depended on only one technique.

With this in mind, perhaps our first consideration should be whether there is any direct evidence that the lead and line and the sounding rod were, in fact, used by sailors in the North Sea between the years 400 and 1200. Records regarding the voyages made during that period are sparse and there is no reason to expect that such a routine practise as measuring depth of water would have caught the attention of scribes. However, what appear to be illustrations of the use of these aids are included in the Bayeux Tapestry.

Figure 7 shows Harold Godwin's ships approaching the coast of France. A man at the bows of the first ship is wielding what seems to be a sounding rod, perhaps doubling as a punting pole in the same way that the boathook, used by Erskine Childers' character, Davies, was also used as a sounding rod. However, the marking of the pole at intervals of what might well be a quarter of a fathom, strongly suggests that its function was primarily for measuring the water depth. The man angles the rod forwards, as one would expect, so that it will become vertical as the ship progresses, to give a reliable measure of the water depth.

Figure 8 similarly shows Harold's ships approaching the coast of Ponthieu, with Harold, himself, being apprehended. However, what looks very like a lead-line, 


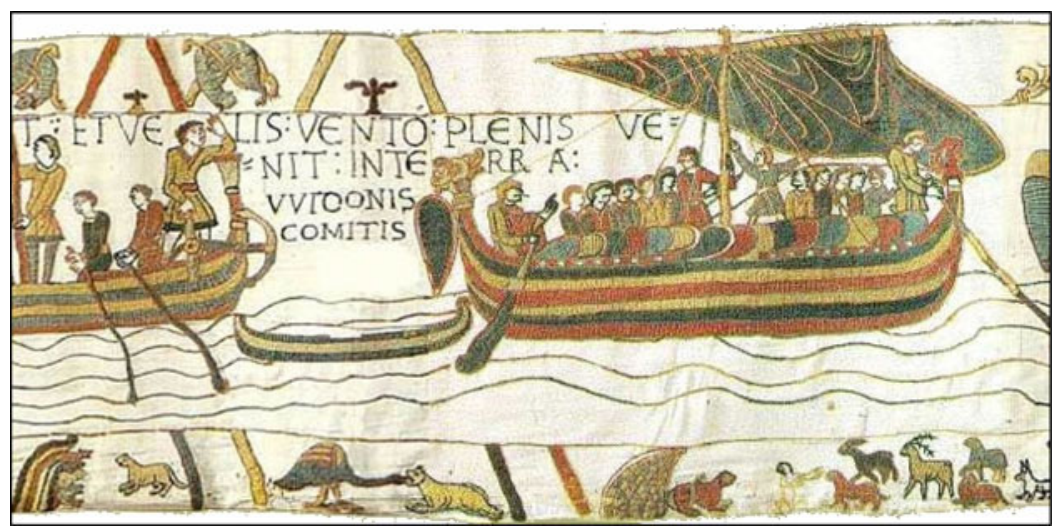

Figure 7. Scene 5 from the Bayeux Tapestry, showing possible use of a sounding pole.

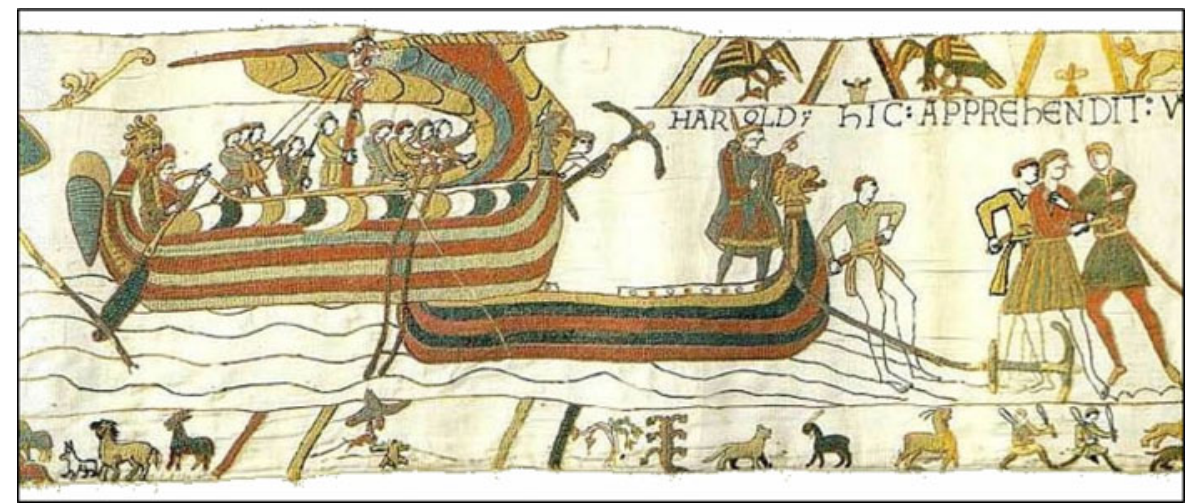

Figure 8. Scene 6 from the Bayeux Tapestry, showing the possible use of a sounding line.

leads forwards from the second ship, as it would do when cast, so that, as the ship progresses, the line would become vertical and the depth of water could be accurately measured. The man in the bows appears to be ready to let go his anchor when an appropriate depth of water is found.

The context of taking soundings when approaching an anchorage is significant, and it is difficult to suggest what else the line might be. It is too thin to be an anchor cable or a mooring line.

This evidence strongly suggests that the use of sounding rods, and lead and line in Roman ships, continued throughout the "Dark Ages" on Saxon and other northwest European ships. This conclusion is supported by the existence of the Old English word, metrap for a sounding line, the word, sundgyrd for a sounding pole and the word fæthm for fathom.

The next illustration of lead and line known to the author did not appear until 1555 (see Figure 10) when it was included in the original Latin version of Olaus Magnus' 
A history of the Northern People, translated into English in 1558. Soon afterwards, in 1584, the two main figures on the title page of Waghenaer's well known masterpiece, Spiegel de Zeevaerdt (later anglicised as The Mariner's Mirror) are both shown casting lead-lines. This clearly illustrates the importance accorded to the lead and line at that time.

7.1. North Sea sailings. We now turn to the kind of voyages that might have been made by early sailors in the North Sea. Would they have embarked on open sea crossings, or did they prefer to hug the coast as far as possible?

Among historians there is some disagreement between those who believe the early southern North Sea mariners followed the coastline and others who believe that some, at least, struck out more directly across the open sea. For example, CrumlinPedersen (1990) suggests that "Rowing techniques did not change the fact that navigation was still based on landing or mooring offshore every night: except for the crossing of straits. Thus, all movements from Jutland to Britain were bound to be along the coastal regions of Lower Saxony and the Netherlands." He also notes that "It was possible to row in sheltered waters almost all the way from the West Coast of Jutland at Esbjerg to the entrance to the English Channel, East of Calais."

Other historians (e.g. Pye, 2014) suggest that it was actually safer to make the crossings in the open sea, away from shoals and strong tidal streams, a view with which the author believes most sailors would agree. For seamen, the shore-line is a source of danger due to the risk of stranding or foundering in the breaking seas. A lee shore would have been a nightmare for the crews of ships that could not beat into the wind. The idea suggested by some, of travelling by day and spending each night ashore, would have been impracticable because landing would have had to have been made some time before night-fall, and the suitable tidal conditions would only occasionally have fallen in an appropriate time bracket. As noted in a paper edited by Ejstrud and Maaleveld (2008), ".... The concept of always finding shelter after a day trip is simply inapplicable in this environment (i.e. the west coast of Denmark) due to shallow waters and strong currents that are prevalent in these areas; one should be ready to find deeper waters to ride out a storm, as the coast is not always approachable."

As already mentioned, there was large-scale migration of Germanic tribes across the North Sea during the $5^{\text {th }}$ and $6^{\text {th }}$ centuries and Ejstrud and Maaleveld (2008) tell us that, "During the $7^{\text {th }}$ and $8^{\text {th }}$ centuries, trade flourished, due in part or mainly to favourable conditions on the North Sea at that time. Piracy was the only disrupting factor. By the $8^{\text {th }}$ Century the four known ports in England that traded with northern France and the Low Countries were Southampton, Ipswich, London and York." It is significant that three out of four of these ports are facing eastwards across the North Sea, implying direct routes to the Netherlands, and possibly also to what are now Germany and Denmark.

Also, due to Ejstrud and Maaleveld (2008) we have Figure 9 which illustrates trading links between the $5^{\text {th }}$ and $9^{\text {th }}$ century as evidenced by findings of pottery, glass, ornaments and coins. Such findings do not necessarily imply direct links, so the direct link shown between East Anglia and Jutland could have been via the Netherlands and Saxony. Conversely, there might have been a direct link across the sea from York rather than via East Anglia or London. However that might be, it seems certain that there was considerable direct trading across a minimum of one hundred miles of the southern North Sea from the Netherlands to East Anglia, and much longer voyages further north to and from York.

Because of the paucity of hard evidence about "Dark Ages" navigation, it is tempting to speculate as to the methods the North Sea sailors might have used, but there are 


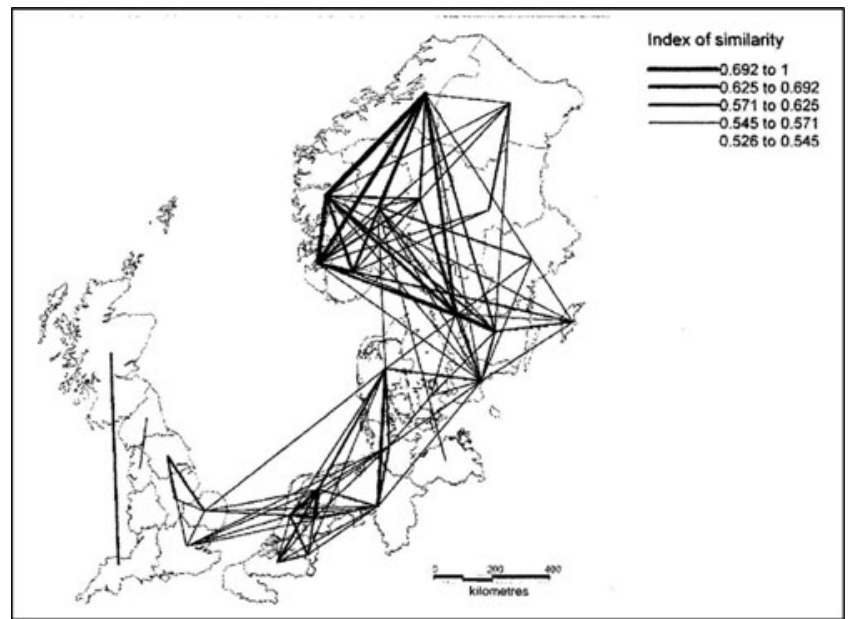

Figure 9. Trade routes from $5^{\text {th }}$ to $9^{\text {th }}$ century, from Ejstrud \& Maalevelde (2008) with their kind permission.

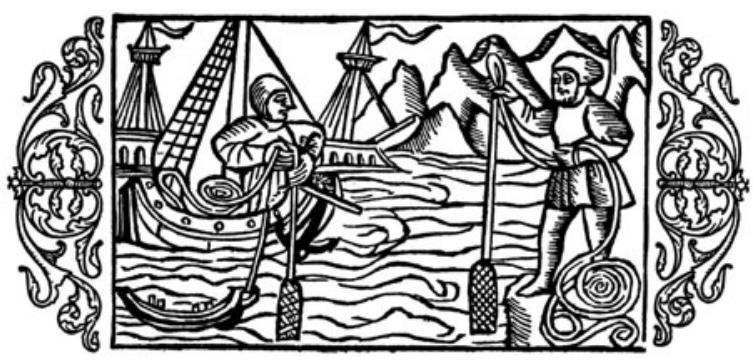

Figure 10. "On the vast depths of the Norwegian Coast" (Magnus, 1555).

two recorded voyages that at least provide a starting point. These are the $9^{\text {th }}$ century voyages of Ohthere and Wulfstan as related to the court of Alfred the Great of Wessex and recorded in an Old English translation of a historical work by the $5^{\text {th }}$ century author, Paulus Orosius. For modern English translations of the voyage descriptions, see Winroth (2006).

7.2. Ohthere's Voyages. The Norwegian, Ohthere, lived in Halgoland (probably near present day Troms $\varnothing$ ). His first voyage was an exploration along the north coast of Norway and then eastwards as far as the White Sea. He kept the land to starboard and the open sea to port.

Later, Ohthere sailed southwards, initially with the coast to port and Iceland ${ }^{1}$ to starboard, and then with "the islands which are between Iceland and Norway" to

\footnotetext{
${ }^{1}$ The Old English record says "Iraland" which is often translated as "Ireland", but, in this particular case, Iceland makes more sense geographically, so that the "islands between Iceland and Norway" would have been the Faroes and the Shetlands.
} 
starboard. This brought him to Sciringes Heal, a trading port in the south of Norway. When he continued his voyage, southwards from Sciringes Heal, he said that he had Denmark to port and the open sea to starboard for three days and then for two days he had Jutland and Sillende and many islands to starboard until he reached Hedeby in the far south-east of what is now Denmark.

As will be discussed later, although he described the relative position of geographical entities, such as countries, in terms of north, south, east and west, when sailing he described the direction of landmarks as to port or starboard.

Ohthere's normal practice was to sail by day and anchor (or camp) each night. This strongly suggests that he navigated mainly by visually following the steep coastline of Norway. Indeed, the deep water close to the shore meant that soundings would have been of little value for his general navigation. However, that same deep water meant that he would have needed to take soundings with lead and line before anchoring each evening so that the anchor was not let go into a depth of water greater than the length of the attached cable. This procedure is illustrated in Figure 10 which is taken from The History of the Northern Peoples (Magnus, 1555). This was published in 1555 , but it is a history, so it probably relates to practices in earlier times. It shows a ship approaching the coast of Norway, with a lead-line being cast and an anchor ready for dropping in a manner that is strikingly similar to Harold Godwin's ship in Figure 8. Figure 10 also shows a man taking a sounding from the shore, who might have been demonstrating how deep the water was and how near the ship could safely approach.

There were no charts available in Ohthere's day, but he appears to have used a mental map which was centred on his ship in relation to identifiable land features on each side. It is of particular interest that he positioned his ship, not only in relation to the coast of Norway, which was in sight, but also to Iceland and, later to the Faroe and Shetland Islands, which were all well beyond his visual horizon. Of course, his way-finding would have been mainly based on recognising features of the Norwegian coast, but he also seems to have been using a similar concept to that used by Micronesian (and possible Polynesian) navigators as reported by Gladwin (1970), Lewis (1970) and Finney (1993). The Micronesians assessed the progress of their canoes in relation to their estimate of the changing bearing of an "etak" island that was out of sight and, ideally, sufficiently far to one side or the other of their course that it could be used as a virtual reference for a complete leg of a voyage. Iceland, the Faroes and the Shetlands were sufficiently far away that they could have been used for this purpose for the section of Ohthere's voyage from Halgoland to Sciringes Heal.

7.3. Wulfstan's Voyage. This voyage was made in the southern Baltic Sea from Hedeby in south-east Denmark to Truso (near present day Gdansk). As an AngloSaxon who later attended at King Alfred's Court, Wulfstan would have certainly also spent time in the North Sea where he would, no doubt, have used similar navigational methods.

Unlike Ohthere, Wulfstan sailed non-stop and completed the passage from Hedeby to Truso in seven days and seven nights. He describes his voyage in terms of the land he passed on the starboard side (Wendland) and the succession of islands and lands he passed on the port side (Langeland, Lolland, Falster, Skane, Bornholm, Blekinge, More, Oland and Gotland.) The first three of these islands would certainly have been in sight for Wulfstan's guidance, but the last two, Oland and Gotland, would 
have been around 50 and 100 miles away, respectively; far beyond Wulfstan's horizon, but well placed to act as "etak" islands for the final leg of his voyage.

Sailing at night means that the ship must have kept well offshore to be sure of not running aground in the darkness. Crumlin-Pedersen (1983) suggests that Wulfstan might have followed the 10 metre depth contour or the 20 metre depth contour for this purpose, by sounding with lead and line. That would certainly have been feasible, once clear of Falster, for the long run along what is now the Polish coast. We recall the following of depth contours by the fictitious Davies and the real Jac Spaans as noted in Section 5 .

7.4. Mental maps?. Whether or not Wulfstan followed depth contours, it is striking that the two Dark Ages sailors who left accounts of their voyages appear to have used something very like the Micronesian "etak" concept to keep track of their progress in relation to islands that were many miles beyond their visible horizon.

Perhaps we should not be too surprised by this. In both cases, we had navigators with no experience of physical maps or charts devising a mental map which was centred on their boat. Thus they spoke of the direction of landmarks in terms of a boat-centred frame of reference (port and starboard) rather than a geographical frame of reference (e.g. north and south). They could estimate their progress by observing, or imagining, the rate at which geographical features moved relatively in the opposite direction. It is possible that, at any stage of a voyage, they could have pointed to a landmark, or "etak" island, beyond the horizon, as the Micronesians were able to do. Animals are known to use similar techniques for estimating their velocity and distance travelled by sensing the apparent angular velocity of fixed objects as they stream past on either side, albeit on a much smaller scale (Srinivasan et al., 1999). Finally, there is neurological evidence that humans, as well as animals, possess cognitive maps that underlie their spatial navigation (Jeffery et al., 2004). The cultures of the Saxons and the Pacific Islanders were very different, but the structure of their brains would have been similar.

7.5. Viking Navigation. From around 800 AD, the Vikings became the dominant force on the North Sea, due, in large part, to the superior design of their ships and the fighting prowess of their warriors (Jones, 1973). Their home waters were in the northern part of the North Sea, where coastlines were steep and offshore depths of water much greater. Visual navigation in relation to prominent land features would have been important and, in good visibility in sight of land, probably sufficient. When out of sight of land, they certainly used the direction of the Sun for keeping a course. They may also have used the Sun to estimate what was, effectively, latitude for maintaining their east-west courses during their voyages to Iceland and Greenland (Marcus, 1980), perhaps measuring its height at noon by a solskuggefjol or Sun shadow board, as suggested by Thirslund (2007). The Pole Star was also important enough to have been given the name Leitharstjaerma or leading star although it would not have been visible, except in the short periods of darkness, during the summer sailing season. As noted previously, it is likely that the earlier North Sea sailors would have used the Sun and stars for maintaining an approximate course, but the Vikings appear to have also developed a sun-compass for more precise measurement of direction (Thirslund, 2007).

Although the Vikings possessed considerable expertise in deep-sea navigation, they would have had to rely on the lead and line for finding suitable anchorages and, also, together with the sounding rod, when approaching the wide, shallow and shoal strewn 
estuaries of the southern North Sea. However, as with the Frisians before them the author has been able to find little record of their actual techniques.

7.6. Roger of Howden's voyage. Roger of Howden (or Hoveden) was a chronicler who, amongst other writings, described a sea-route from York to Palestine, as used by King Richard the Lionheart for carrying armies and supplies to participate in the Third Crusade. The first leg of this voyage, from York to Dartmouth, has been translated from the original Latin by Paul Harvey and Mike Spence (Hughes, 2012).

Howden's sailing directions date from 1190, but they are clearly based on knowledge that had accumulated among sailors, and been passed down orally over a considerable period of time. He was an administrator, possibly having taken Holy orders, and the information he recorded came partly from his own observations, but mainly from the sailors with whom he sailed.

He advised that sailors, taking the route from York to Dartmouth, should keep England on the starboard side and should not go far from land. This underlies the importance given to visual navigation. On the other hand, the next leg, from Dartmouth to Brittany required an open ocean voyage of some 90 miles. This clearly held no fears for sailors since they could have crossed to the French coast by much shorter distances across the Dover Strait or from the Solent to Normandy. The Dover Strait crossing might have been avoided because King Richard's Angevin Empire did not include Calais, but crossing to Brittany would have allowed sailing along a coastline under Richard's control all the way to the Spanish border.

In his Sailing Directions, Howden gave great attention to sandbanks, listing them by name and position. For example, he identified nearly twenty on the river journey from York to the North Sea. This information could only have been given to him by the sailors who, in the absence of any kind of chart, must have carried it in their heads in the form of some sort of mental map. When heading upstream and making use of a flood tide, awareness of sandbanks would have been useful to avoid running aground although, on a rising tide, a ship could readily have been re-floated. When heading downstream and making use of an ebb tide, knowledge of the location of sandbanks would have been vital. A ship stranded on a falling tide would have had at least a long wait to be re-floated and, if the ship had been left at an awkward angle, the following flood tide might have filled the ship with water rather than re-floating it.

Knowing approximately where the sandbanks were would have allowed sailors to follow channels with sufficient depth of water by the appearance of the surface or by a bow-man using a sounding rod to follow depth contours along the edges of the banks, just as described by Childers (1903) for his character Davies. In cases of doubt as to whether a bank was to port or starboard, the bow-man could have used his rod to sound, alternately on each side. This technique was brought to a high level of precision by nineteenth century Mississippi pilots (Twain, 1883) who, when required, used a leadsman on each bow, thus giving information, not only of the depth of water, also of the slope of the bank that the ship was skirting.

Off the coast of England, Howden identifies many sandbanks. He rarely specifies an actual depth of water because such depths vary with the state of the tide, but he does mention the nature of the sea-bed on two occasions. For example, he describes it as "stony" off Foulness on the East Coast and as "sandy" at Dover, and one can make what one likes of the fact that at Foulness the sea-bed in now mostly sand and at Dover it is bare chalk rock or flint gravel. In many cases, Howden tells of sandbanks which are safe to cross when the height of tide is "full" or, perhaps, "above middling". 
Clearly there is much work for a lead and line in these offshore areas, although he makes no specific mention of it.

Finally, Howden lists ports and anchorages that he passed on his voyage from York to Dartmouth, and he gives details regarding their safety and the size of ship they can accommodate. Anchorages would have been important to sailors for riding out an adverse tidal stream until it turned in their favour. When making use of a favourable tidal stream, a fair wind would have provided steerage way and allowed the helmsman to control the ship. In the absence of a fair wind, Hughes (2012) suggests that "the master maintained direction by kedging ${ }^{2}$ an anchor as the tidal stream powered the ship on."

This method of controlling a ship in a strong tideway would have been particularly useful in rivers. It is likely to have been used by early North Sea sailors because it had a long history. Holmes (1906) reports that a similar technique was used by the Ancient Egyptians:

Down-stream they travel as follows: they have a door-shaped crate, made of tamarisk wood and reed mats sewn together, and also a stone of about two talents' weight, bored with a hole; and of these the boatman lets the crate float on in front of the boat, fastened with a rope, and the stone drag behind by another rope. The crate then, as the force of the stream presses upon it, goes on swiftly and draws on the boat while the stone, dragging after it behind and sunk deep in the water, keeps its course straight.

7.7. Knowledge of tides. Tidal streams and tidal heights must have been of great importance to sailors plying the North Sea during the Dark Ages. They are not mentioned in Ohthere's account of his voyages, and Wulfstan's voyage was made in the Baltic Sea which had no significant tides.

Richard of Howden's sailing directions did make frequent mention that a tide needed to be "full" or "more than middling" in order for a ship to pass over a bar or to enter a port. However, he gave no clue as to how the state of the tide at the place in question might have been deduced from the position of the Moon and, perhaps more surprisingly, he makes no mention of the strength and direction of tidal streams to be found in any of the places he visited. However, it appears that he assumes sailors had a good working knowledge of the state of the tide when approaching their various ports and anchorages.

The Venerable Bede (725 AD) in his De Temporum Ratione (The Reckoning of Time) confirmed the link between the movement of the Moon and the timing of the tides based on classical works and on his own observations. He established that both the daily lunar retardation and the average daily tidal retardation had the same value of 48 minutes. He also recorded what was no doubt already known by the seafaring Saxons among whom he lived, that the maximum tidal range and the fastest tidal streams occurred at full Moon and new Moon (spring tides) and that the minimum tidal ranges and the slowest tidal streams occurred at quarter Moons (neap tides).

\footnotetext{
${ }^{2}$ Kedging, in this context, means towing an anchor astern on a sufficiently short length of cable that it creates a dragging force which keeps the ship aligned with the tide but does not "bite" into the river bed and bring the ship to a standstill.
} 
The Saxons, and other "Dark Ages" sailors would not have taken Bede's scholarly approach, but they would surely have acquired a good working knowledge of the behaviour of the tides in their home areas and in the places to which they regularly traded. Over many years, this information became consolidated so that, by the $14^{\text {th }}$ Century, the first English rutter provided information for finding the time of high water at many ports, and on the rates and directions of tidal streams (Taylor, 1956).

8. DISCUSSION. Having considered the use of soundings for navigation during the periods before and after the Dark Ages, we then considered some of the few records of how ships were navigated during that period.

With the possible exception of the Sun Compass, and possibly the shadow board, in the late Viking period, the sounding rod and the lead-line were the only navigation aids available during the Dark Ages. From evidence already discussed, it is almost certain that the North Sea navigators used these devices, but it is not easy to be sure to what extent.

For convenience of discussion, we look at three aspects of their navigational tasks. Track keeping would have been the most important. By carefully following a preplanned track a ship would eventually arrive safely at its destination. Keeping a reckoning of the distance travelled along track would have been of lesser importance except towards the end of a voyage where it might be important to make a landfall in daylight or to approach a destination at the time of high tide. Position fixing would have been of doubtful value in the absence of maps or charts, except insofar as a position could be related to "cross-track" and "along-track" displacements. These three aspects are discussed in turn.

8.1. Track Keeping. Although charts did not exist, sailors would have known where shoal water and sandbanks were located. In rivers and estuaries, it seems likely that, as was the case with Erskine Childers' Davies, they could find their way with some accuracy, by using sounding rods to follow depth contours. When navigating off low-lying and undistinguished coastlines in the southern North Sea, they might have used the lead line to follow deeper depth contours which often run parallel to the coast.

The northern North Sea and the English Channel coasts had distinctive features and, in many cases, deep water close to the shore so that visual navigation would have been sufficient to allow sailors to follow the coast at a safe distance, but the lead line would still have been a vital aid when approaching land to anchor or to enter a port.

Voyages which took the sailors out of sight of land were certainly made, as narrated by Wulfstan, and as specified by Howden for the leg of his voyage from Dartmouth to Brittany. Pye (2014) suggests that Frisian traders probably made direct voyages across the North Sea to London and York and, from the $7^{\text {th }}$ century, to Ipswich, evidenced, for example, by a Frisian colony known to have existed in $8^{\text {th }}$ century York. Similar voyages to the east coast of Britain might also have been made by Germanic migrants. From around $800 \mathrm{AD}$, Viking raiders made light work of crossing the North Sea, culminating with Harald Hardrada (King Harald III of Norway) sweeping across with between 200 and 300 ships from Sognefjord in Norway to Tyneside in Britain via the Shetland Islands and the Orkney Islands in 1066 (Jones, 1973).

Parts of such voyages would have been out of sight of land, and the early sailors would have had to maintain a track as best they could by using directional 
information from the Sun and the stars, perhaps aided by a Sun compass in the case of the Vikings.

8.2. Progress along track. Distance travelled along track, when following a welldefined and familiar coast, could have been monitored as a ship passed known promontories or other landmarks. When the land was ill-defined or out of sight (which would have often happened in the misty North Sea) the sailors would have had to depend on a kind of intuitive dead-reckoning to estimate the distance they had travelled. For this purpose, it seems likely that they used a mental map but, in the absence of charts to form a reference, this might not have been the kind of mental map that we are conditioned to imagine. There is intriguing evidence, from the voyages of Ohthere and Wulfstan, that the early North Sea navigators might have kept a reckoning of their progress by a mental process similar to the Micronesian "etak" concept which was used until recent times by Micronesian navigators. However, this remains little more than speculation.

It has already been mentioned that depth contours often run parallel to an adjacent coastline so it can be useful to follow a depth contour when making a coastwise voyage. When approaching a destination from seawards, that same configuration means that depth contours provide a reliable indication of "along-track" progress, giving an experienced navigator information about the distance he still has to go at a critical stage of his voyage.

8.3. Position. The way we think of the position of a ship, in terms of latitude and longitude, would have been outside the experience of "Dark Ages" sailors.

Also a matter of speculation is the extent to which early North Sea sailors used the nature of the sea-bed to inform their navigation. Beyond two brief mentions by Howden, the author knows of no direct evidence that they made use of this particular clue. The depth of water, especially in coastal areas, depends on the state of the tide, so the fact that the nature of the sea-bed is independent of the state of the tide, makes it an attractive measure of location.

As noted in Section 2, the nature of the sea bed was recognised as an important navigational clue by the Ancient Egyptians. Many of the sounding weights described by Oleson (2008), from and including the Gela wreck (c. 500 BC), had a tallow cup in their bases for sampling the seabed. This is evidence that the technique of bottom sampling continued in the Mediterranean through Hellenic and Roman times. After several hundred years of Roman influence in the North Sea, it is likely that a similar practice would have been adopted there, even if it had not already been developed independently.

In more recent times, we know that it was possible for a North Sea fisherman to navigate out of sight of land using only water depths and sea-bed samples. In order to do this he must have accumulated an encyclopaedic knowledge of the pattern of depths and sea-bed material over a large area of the southern North Sea. Furthermore, wherever he positioned his trawler within this mental map, he would have known the course to steer for Lowestoft. It is unlikely that any Dark Ages sailors would have had the opportunity to build up such a large body of knowledge but, in their local areas, they would surely have been well aware of the sea-bed topography and have understood how to read it, and those who made regular voyages further afield would almost certainly have learned to use depths and samples of seabed material for positioning, and thence to find their way to their destination. 
9. CONCLUSIONS. There is a great deal that we do not know for sure about "Dark Ages" navigation techniques in the North Sea, but we do know there was much maritime traffic for trading, migration and raiding during that period. We also know that the sailors concerned were able to find their way to and from their chosen destinations with sufficient accuracy for their purpose. Evidence from later times confirms that there is a great deal of navigationally useful information contained in the seabed. Early North Sea sailors would almost certainly have made use of this, but the extent to which they did so is a matter of conjecture.

Clearly the early North Sea sailors achieved a high level of expertise on the basis of their personal experience and, without doubt, from a store of accumulated knowledge passed down verbally from generation to generation. Plying the North Sea in an open boat was (and is) a dangerous occupation. Those who did not develop a high level of competency would surely have not long survived.

\section{REFERENCES}

Bede (725) Trans. Wallis, F. (1999). The Reckoning of Time. Liverpool University Press.

Childers, E. (1903). The Riddle of the Sands. Smith Elder \& Co. London.

Cleere, H. (1978). Roman harbours in Britain south of Hadrian's Wall. CBA Research Report No. 24.

Cooper, R.W. (2010). Heaving the Lead. The Journal of Navigation, 63, 183-186.

Crumlin-Pedersen, O. (1983). Skibe, sejlads og ruter hos Ottar og Wulfstan, in Ottar og Wulfstan, to rejsebeskrivelser fra vikingetiden, Lund, N., ed., pp. 32-44. Roskilde: TheViking Ship Museum.

Crumlin-Pedersen, O. (1990). The Boats and Ships of the Angles and Jutes, in Maritime Celts, Frisians and Saxons, Sean McGrail, ed. Council for British Archaeology.

Ejstrud, B. and Maarleveld, T.J. (eds.). (2008). The Migration Period, Southern Denmark and the North Sea. Maritime Archaeology Programme, University of Southern Denmark, Esjberg.

Finney, B. (1993). Rediscovering Polynesian Navigation through Experimental Voyaging. Journal of Navigation, 46, 383-394.

Gladwin, T. (1970). East is a Big Bird. Harvard University Press.

Hassall, M. (1978). Britain and the Rhine provinces, epigraphic evidence of Roman trade. CBA Research Report No. 24.

Hawkins, Sir R. (1593). The Observations of Sir Richard Hawkins Knight in his Voyage into the South Sea. Hakluyt Society, 1847. P. 52,53.

Herodotus. (440BC). History, Book 2. See online translation by G. Rawlingson at classics.mit.edu/ Herodotus/history.2.ii.html

Holmes, Sir G. C. V. (1906). Ancient and Modern Ships. Part 1, para 25. Victoria \& Albert Museum Science Handbooks. (Online at Project Gutenberg).

Hughes, P. (2012). Roger of Howden's Sailing Directions for the English Coast. Historical Research, 85, no. 230, 576-596.

Jeffery, K J, Anderson, M I, Hatman, R. and Chakraborty, S. (2004). Studies of the hippocampal cognitive map in rats and humans. Online at: www.ucl.ac.uk/jefferylab/publications/2004

Jones, G. (1973). A History of the Vikings. Oxford University Press.

Lewis, D. (1970). Polynesian and Micronesian Navigation Techniques. Journal of Navigation, 23, $432-447$.

Lowe, D.J. (2008). Polynesian settlement of New Zealand and impacts of volcanism on early Maori society: an update. In Guidebook to Pre-Conference North Island Field Trip. New Zealand Society for Soil Science, pp143-147.

Magnus, O. (1555 Latin, 1558 English). The History of the Northern Peoples. Originally published, Rome.

Mainwaring, Sir H. (1644). The Seaman's Dictionary, included in The Life and Works of Sir Henry Mainwaring, Vol. II, printed for the Navy Records Society, London, 1922.

Marcus, G.J. (1980). The Conquest of the North Atlantic. The Boydell Press, Woodbridge, Suffolk.

May, W.E (c. 1970). Sounding with lead and line. Unpublished notes, held by the Cundall Library, Royal Institute of Navigation, London.

May, W.E. (1973). A History of Marine Navigation. G.T.Foulis \& Co. Ltd, Henley-on-Thames. 
Norie, J.W. (1822). Complete Epitome of Practical Navigation, $7^{\text {th }}$ Edition. Published by J.W. Norie \& Co, London.

Oleson, J.P. (2008). Testing the Waters: The Role of Sounding Weights in Ancient Mediterranean Navigation. In Vol. 6, "The Maritime World of Ancient Rome," pp. 117-174. Published by Memoirs of the American Academy in Rome.

Phillips, C., Schmidt, K.K. and Muheim, R. (2005). True navigation: Sensory Bases of Gradient Maps. From "Animal Spatial Cognition", ed. and published by M.J. Brown and R.G. Cook.

Pye, M. (2014). The Edge of the World. How the North Sea made us who we are. Viking Press.

Srinivasan, M.V., Chahl, J.S., Weber, K., Venkatesh, S., Nagle, M.G. and Zhang, S.W. (1999). Robot navigation inspired by principles of insect vision. From: Robots and Autonomous Systems 26, 203-216.

Strabo. (20 AD). Geography - Book IV, Chapter 4, paragraph 1.

Taylor, E.G.R. (1957). The Haven Finding Art. Abelard - Schuman Ltd. New York.

Thirslund, S. (2007). Viking Navigation. Roskilde.

Towne, W.F. (2008). Honeybees can learn the relationship between the solar ephemeris and a newly-experienced landscape. The Journal of Experimental Biology, 211, 3737-3743.

Twain, M. (1883). Life on the Mississippi. James R. Osgood \& Co. Boston.

Walcott, C. (1996). Pigeon Homing: Observations, Experiments and Confusions. Journal of Experimental Biology, 199, 21-27.

Winroth, A, (2006). Viking sources in translation. The accounts of Ohthere and Wulfstan. On-line at https:/l classesv2.yale.edu/access/content/user/haw6/Vikings/voyager 